\title{
The Reality of the role of Jordanian Universities In Promoting Moderate Ideologies among Students Based on Amman Message
}

\author{
Reem Mushref Ahmad Al Efan $\quad$ Prof. Mohammed Amin Al-Qudah
}

\begin{abstract}
The present study aimed to explore the reality of the role of Jordanian universities in promoting moderate ideologies among students based on Amman Message from the students' perspective. It aimed to explore whether there is any significant difference between the respondents' attitudes which can be attributed to gender, faculty, university, academic year, program and GPA. The sample consists from 400 students. Those students were selected from the University of Jordan, Yarmouk University, and Mu'tah University. A questionnaire was developed. It consists from 40 items. It sheds a light on 4 areas. These areas are: (faculty members, students, student union, and university activities). It was found that Jordanian universities play a moderate role in promoting moderate ideologies among students based on Amman Message from the. That's because the overall mean is 3.41 which is moderate. The mean of the (faculty member) area is 3.48. It's moderate and ranked first. The mean of the (student) area is 3.45. It's moderate and ranked second. The mean of the (student union) is 3.39. It's moderate and ranked third. The mean of the (university activity) area is 3.32. It's moderate and ranked last. It was found that there is a significant difference between the respondents' attitude which can be attributed to faculty. The latter difference is for the favour of the ones enrolled in human sciences faculties. It was found that there is a significant difference between the respondents' attitude which can be attributed to university. The latter difference is for the favour of the ones enrolled in the University of Jordan. It was found that there is a significant difference between the respondents' attitude which can be attributed to academic year. The latter difference is for the favour of the freshmen. It was found that there is a significant difference between the respondents' attitude which can be attributed to GPA. The latter difference is for the favour of the ones whose rating is (very good). It was found that there isn't any significant difference between the respondents' attitude which can be attributed to gender or program. The researchers recommend promoting moderate ideologies among students. They recommend promoting awareness among students about awareness among students about the significance of moderate ideologies. They recommend fighting against extremist ideologies. They recommend carrying out activities to promote moderate ideologies among students. They recommend moderate ideologies among students through the student union. That shall contribute to the development of balanced personalities
\end{abstract}

DOI: $10.7176 / \mathrm{JEP} / 11-20-09$

Publication date:July $31^{\text {st }} 2020$

\section{Introduction}

Some countries -including Arab and Islamic countries- suffer from extremism, radicalism and terrorism. That is attributed to wars. Wars increased the rates of poverty, unemployment, ignorance, oppression and instability. They hindered nations from development. They negatively affected societies, and young people. They led to the spread of pessimism. Due to such pessimism, many young people started to adopt extremist ideologies. The prevalence of such ideologies led young people to adopt wrong values. It negatively affected the identity of each society.

Terrorism has been increasing dramatically. It is a complex and confusing phenomenon. There are several reasons leading to the spread of terrorism. Such reasons have several negative impacts on society. For instance, they negatively affect the order in society. They negatively affect the psychological security of people in society. Due to such reasons, it has become necessary to fight against terrorism. Hence, many researchers, and ideologists who seek promoting moderate ideologies are fighting against terrorism through conducting studies about it. Although terrorism isn't something new, there is an urgent need for fighting against it. Such urgent need is attributed to the increasing number of terrorist acts and the emergence of new types of terrorism. It's attributed to the spread of terrorism across many countries. It's attributed to the emergence of new methods for committing it (Al-Ghool and Al-Qudah, 2019).

Societies seek fighting against terrorism through educating people. Through education, people's behaviours are adjusted and people's attitudes are changes. It should be noted that education significantly affects one. That's because education teaches one the way he/she ought to live his/her life. It's because education enables one to meet his/her goals and life demands. In addition, education enables one to handle challenges and regulates one's behaviour. Through regulating one's behaviours, one shall be capable to integrate into society. Through education, the cultural heritage shall be transmitted from one generation to another. Education enables people to eliminate the defects in their cultural heritage. In other words, it contributes to the survival, development and growth of society (Naser, 2011). 
Young people are the fortune of any nation. That's because they play a significant role in improving the future and present of nations. Young people are ones who shall lead the nations in the future. Hence, societies seek raising up young people properly. They aim at developing young people to become capable of handling important responsibilities in the future. The fortune of the Islamic nations are presented in young people rather than natural resources which are considered non-renewable. Due to the significant role of young people, there must be much attention given to them. Providing them with much attention shall contribute to developing nations (Al-Zoby\& Al-Qudah , 2020 Fallouh\& Al-Qudah , 2020, Mohammad \& Al-Qudah, 2020, Ben Tarif\& AlQudah, 2019 ؛Hatahet\&Alqudah, 2016 ؛Al-Hammad\& Al-Qudah,2019,1, Al-Hammad\& Al-Qudah,2019,2, Alqudah\&Hindi, 2019؛Malkawi, \&Al-Qudah, 2018,2; Al-Qudah, 2017; Thatha et al., 2012; Zaqzooq, 2012).

In the light of the aforementioned information, educational institutions- including universities- should provide much attention to young people. For instance, universities should develop young people and improve their ways of thinking. They must provide young people with knowledge. They must prevent the prevalence of extremist ideologies among young people. They must promote dialogue-related values among young people. They must promote acceptance for different opinions among them. It's necessary to promote positive values and ideologies among youth in universities. That is because the attitudes and ideologies of youth in universities are still developing during this stage.

Universities hold various events and must meet several responsibilities. They provide students with many opportunities in order to develop their personalities in all aspects. University students can develop themselves through seizing such opportunities and utilizing their potentials efficiently. They can develop themselves through managing their time efficiently (Abu Amshah\& Al-Qudah , 2020, Fallouh\& Al-Qudah , 2020،, Al-Qudah\& AlHathal, 2019; Al-Turk and Al-Qudah, 2017, Hamadneh and Al-Qudah, 2017, Al-Hasnawi, 2010).

According to Al-Fraijat (2009), universities must carry out several responsibilities. Such responsibilities include: conducting scientific research. The amount of attention given to scientific research reflects how advanced and civilized the society is. Universities must identify the problems and challenges facing society. They must propose solutions for addressing such problems and challenges. In addition, they must deliver public services. That is done through delivering scientific services. They must deliver advice and information that are beneficial for the members of the society, intellectual leaders and institutions. That is because universities have experts and references in various fields. They must make regular assessments for reality.

In the light of the aforementioned information, educational institutions- especially universities- must provide much attention to young people. That is because young people play a significant role in developing societies. Universities must provide young people with knowledge and information. They must promote awareness among young g people about the risks facing their nation. They must promote moderate ideologies among young people. Such ideologies are derived from the cultural, religious, and historical heritage. Promoting such ideologies shall contribute to the development of society.

Through education, awareness can be promoted among young people about several issues. Educating young people shall enable them to differentiate between good and evil things. It shall enable young people to think properly. It shall instill positive Islamic principles within them. Such principles shall be based on the Holy Quran and Sunnah. It shall contribute to fighting against extremism and close minded ideologies. It shall promote tolerance among the members of the Islamic nation. It shall promote moderate ideologies among them. It shall promote moderate compliance with the Islamic principles. It shall promote mercy among them in the manner mentioned in the Holy Quran (Al-Tamimi\& Al-Qudah, 2019, Alkayed\&Alqudah, 2019; Abu Amshah\& AlQudah , Ben Tarif\& Al-Qudah, 2019 ؛Hatahet\&Alqudah, 2016; Zaqzooq, 2012; Al-Hailat et al., 2008; Al-Qudah, 2006).

Universities must promote moderate ideologies among students. That shall contribute to the development of balanced personalities. According to Al-Shamiand Al-Qudah, (2020)Rahamneh and Al-Qudah, (2016) and AlHasoon (2003), one's ideologies significantly affects his/her life. That is because adopting sound ideologies shall make one more aware about the things surrounding him/her. It shall promote deeper knowledge among people about their existence and relationships with the universe. That is because human adopting sound ideologies shall enable one to realize fact and perceive things from a holistic perspective. Adopting sound ideologies shall provide one with new knowledge.

In the light of the aforementioned information, thinking is a cognitive activity that requires using cognitive skills in order to reach facts. Through thinking, one uses scientific methods for identifying a specific piece of information. Thinking requires using cognitive capabilities. It requires understanding, and analyzing things and reaching a conclusion. It requires looking into things.

According to Al-Bakar (2003), thinking plays a significant role in one's life and society. For instance, it offers one several alternatives in various areas. It enables one and groups to handle crises. It positively affects the state's economy and promotes ethics. It offers solutions for the problems that the society suffers from. It offers such solutions through developing plans and examining the effectiveness of the proposed solutions. It offers such solutions through promoting knowledge about ideal models. 
According to Jbara and Al-Qudah (2018) and Al-Fa'oori (2009), moderate ideologies can be promoted among young people through university and school education. They can be promoted through developing curricula and promoting dialogue-related values among young people. They can be promoted through providing young people with knowledge about the Islamic religion that is based on mercy, peace, and tolerance. That shall make young Muslims reflect a good image about Islam when dealing with others. It shall correct the misperceptions that people have about Islam. For instance, may people today believe that Islam involves extremism, terrorism and violence

In the light of the aforementioned information, it's very significant to promote moderate ideologies among young people through university and school education. Promoting such ideologies is important because they shall manifest through the way of thinking and behaviours.

Moderate ideologies should be adopted by all nations. They must be promoted through curricula in schools, universities, and other educational institutions. They must be promoted through practical and theoretical education. They must be promoted through fighting against fascism and close minded ideologies. They must be promoted through developing students' personalities in order to reflect a good image about the Islamic civilization through ideology and behaviour (Al-Khateeb, 2009).

Moderation involves eliminating extremism in all the aspects of life in terms of ideology and behaviour. Promoting moderate Islamic ideologies shall contribute to the development of balanced personalities.

Amman Message is a significant document. It aims at promoting moderate ideologies. All Muslim scholars suggest that Amman message promotes good values among people. Such values include mercy, justice, tolerance, and moderation. They add that Amman Message aims at fighting against extremism, terrorism and Takfeer. They add that Amman Message aims at correcting the misperceptions that people have about Islam which is a great religion. Amman Message is based on the Holy Quran. It suggests that Islam seek promoting moderation. It is based on the vision of the Hashemite Family. It suggests that people must serve their society and defend Islam and its moderate ideologies (Rababah, 2007).

According to Shdaifat (2005), Amman Message aims at developing one's mind and way of thinking. Shdaifat (2005) suggests that there is a need to developing one's mind and way of thinking through education and curricula. Such development shall contribute to fighting against ignorance and close minded ideologies. It shall contribute to fighting against fanaticism. It shall contribute to promoting tolerance and acceptance for the different opinions. It shall enable people to hold respectful discussions with the ones who hold different opinions in an objective and open minded manner.

Amman message was issued by King Abdullah II bin Al-Hussein. At the time of issuing Amman Message, extremist values were prevalent. At that time, many people were not adopting the moderate ideologies of Islam. At that time, many people were accusing Islam of promoting terrorism and extremism. However, such accusations are false. The ones who make such accusations don't understand the Islamic religion correctly.

According to Khasawneh (2005), Amman Message suggests that Islam seeks promoting tolerance, moderation and openness to other civilizations. It suggests that Islam encourages people to do good deeds and seeks achieving justice and protecting people's rights. It seeks identifying the noble fundamentals of Islam. This religion is based on balance, and moderation and seeks making people's lives easier.

Educational institutions must promote moderate ideologies among young people. They must promote dialogue-relate values and tolerance among young people. They must promote acceptance for ones who are different. They must seeks fighting against extremist ideologies. They must ensure that young people adopt sound ideologies. They must encourage young people to work and serve their societies. They must encourage young people to develop the nations and engage in dialogue with the ones who have difference opinions. They must encourage young people to accept the ones who are different from them. They must promote a culture of tolerance, and peace and fight against isolation and extremism.

Therefore, the present study aimed to explore the reality of the role of Jordanian universities in promoting moderate ideologies among students based on Amman Message from the students' perspective. The researchers aimed to explore such reality in the aim of developing young people and providing them with faith and knowledge. That shall contribute to fighting against terrorism and violence and promoting security and stability

\section{Statement of the Problem:}

Islamic and Arab countries have been suffering from wars. Such countries include countries surrounding Jordan, such as: Palestine, Syria and Iraq. They also include: Yemen, and Libya. These wars have negative impacts on people. Jordan is affected by global and regional affairs. It's affected by social, economic and political conditions. It's affected by immigrants. All these thing contributed to the promotion of extremist ideologies and violence. Many people adopt extremist ideologies and commit violent acts to escape the harsh reality and find solutions for problems.

Jordan has been affected by terrorism. For instance, several terrorist acts were launched against Amman in 2005 by Al-Qaeda. These terrorist acts are called (2005 Amman bombings) that shocked the Jordanian society. 
They were launched against three hotels in Amman. They killed 60 individuals and hundreds were wounded. In addition, in 2014, the Jordanian ambassador in Libya was kidnapped by a terrorist group. He was freed after releasing a terrorist Libyan who was serving time in prison because he was intending to launch a terrorist attack in Jordan.

There are other terrorist attacks. For instance, the Jordanian pilot; Muath Al-Kasasbeh; was burnt in 3-22015 by ISIS. In addition, on 12-12-2016, 10 officers got killed in a terrorist attack in Karak. In 2017,17 terrorists got killed in a terrorist attack in Irbid. In November, 2017, a terrorist attack was aborted. 17 terrorists planned for this attack. They aimed at launching an attack against the New Year celebrations. In August, 2018, a terrorist attack was launched in Fuhais.

Hence, the present study aimed to explore the reality of the role of Jordanian universities in promoting moderate ideologies among students. To be specific, it aimed to answer the following questions:

Q.1. What is the role of Jordanian universities in promoting moderate ideologies among students?

Q.2. Is there any statistically significant difference- at the statistical significance level of $(a=0.05)$ - between the respondents' attitudes?

\section{The Study's Objectives}

The present study aimed to explore the role of Jordanian universities in promoting moderate ideologies among students from the students' perspective. It aimed to explore whether there is any statistically significant difference- at the statistical significance level of $(\mathrm{a}=0.05)$ - between the respondents' attitudes which can be attributed to specific variables.

\section{The Study's Significance}

As far as the researchers know, there aren't many studies that shed a light on the role of Jordanian universities in promoting moderate ideologies among students based on Amman Message from the students' perspective. The present study contributes to the promotion of moderate ideologies among students. It provides the management of universities with beneficial results. Such results shall enable universities to promote ethics, values and moderate ideologies among students. They shall enable universities to promote tolerance, justice, mercy, and freedom, and dialogue-related values. They shall enable universities to fight against extremism and terrorism. They shall contribute to promoting a culture of creativity in universities. The present study offers a proposed vision for improving the role of Jordanian universities in promoting moderate ideologies among students. It enables universities to promote ethics and moderate ideologies among students. It enables universities to fight against extremism and negligence in doing religious duties. It enables universities to promote acceptance for different opinions.

\section{Theoretical and operational definitions}

The theoretical and operational definitions of the study's terms are listed below:

Moderation (theoretical definition): It refers to refraining from showing extremism and negligence (Al-Qardawi, 2011). Moderation (operational definition): It refers to showing balance, and refraining from showing extremism and negligence in order for all people to enjoy their rights.

Moderate ideology (theoretical definition): It refers to an ideology that is based on avoiding excessiveness. However, adopting such an ideology doesn't mean that one shall accept solutions of poor quality. In fact, the one who adopts such an ideology shall seek taking sound steps and meeting the public interests because he/she has a strong faith and trust in Allah (Al-Fa'oori, 2009: p.102).

Moderate ideology (operational definition): It refers to the extent of adopting moderate ideology by students in Jordanian universities in reality. It involves the degree to which those students refrain from adopting extremist ideology and commit extremist behaviour. It involves the degree to which those students promote moderation, tolerance and a culture of dialogue and Islamic values. Such values include: anti-violence values and peace. In this study, the extent of adopting moderate ideology by students in Jordanian universities is measured through the study's instrument.

Amman Message (2004): It refers to a statement that was issued in the twenty-seventh of Ramadan in 2004 (i.e. on Al-Qader Night). This statement was issued by King Abdullah II bin Al-Hussein. It aims at promoting tolerance and unity in the Islamic World. About 200 scholars specialized in Sharia in more than 50 countries suggest that this statement is a great statement. Amman Message provides valid information about Islam. It corrects misconceptions that people have about Islam. It provides knowledge about the acts that represent Islam and the acts that don't represent it. It promotes a good image for Islam that is based on valid information. For instance, it suggests that Islam is based on treating others fairly and protecting others' rights. It suggests that Islam seeks promoting compliance with conventions and agreements. It suggests that Islam forbids treachery and promotes kindness. It suggests that Islam seeks fighting against violence and protecting the right to life of civilians. It suggests that Islam seeks promoting respect for one's dignity regardless of his/her colour, gender, or 
religion (Al-N'aimat et al., 2018).

\section{The Study's Limits}

The present study targets the students enrolled in Jordanian universities during the year 2020. To be specific, the sampled students were selected from the University of Jordan, Yarmouk University, and Mu'tah University.

\section{Previous studies}

This section presents the studies that were reviewed by the researchers. Some of those studies are published in Arabic language and some studies are published in English language. The studies are presented below based on the year of publication from the newest to the oldest.

Al-Harahsheh (2018) aimed to explore the role of the vision of King Abdullah II bin Al-Hussein in promoting moderation. He aimed to explore the reasons that led to forming this vision. He aimed to explore the role of this vision in promoting security and safety in Jordan. He adopted a systematic analytical approach. He used the content analysis method. He used the speech analysis method. Several results were concluded. For instance, it was found that of King Abdullah II bin Al-Hussein adopts a moderate approach. It was found that the dialogue-based approach adopted by the latter king promoted security in Jordan. It was found that the statements made by the latter king played a significant role in promoting democracy in Jordan. Such statements led to promoting knowledge, and moderation and anti-terrorism culture. They led to promoting an anti-violence culture.

Al-Muhammady (2018) aimed to explore the role of schools and universities in fighting against extremism in Malaysia. He aimed to shed a light on the role of faculty members and students in providing support for terrorist groups in Malaysia. He aimed to identify the reasons behind the interest of terrorist groups in recruiting the ones enrolled in students and universities. He aimed to explore the role of schools and universities in fighting against violent extremism in Malaysia. It was found that schools and universities play a significant role in fighting against extremism in Malaysia. It was found that educational institutions serve as a "third power" in fighting against violent extremism and terrorism. It was found that public bodies and intelligence agency play a significant role in fighting against violent extremism. It was found that public bodies and intelligence agency seek detecting violent extremist acts and preventing such acts. They seek educating people about the negative impacts of such acts.

Al-Fayez (2017) aimed to explore the role of Jordanian politicians and their speeches in promoting knowledge about moderation in Islam. He aimed to explore the extent of promoting the values implied in Amman Message through the speeches of Jordanian politicians. It was found that the speeches of Jordanian politicians are based on fixed foundations. These foundations aim at developing the present and future of Jordan. Such speeches indicate that the Hashemite family provide attention to Jordanians. They promote moderation that is derived from figures known in the Islamic and Arab history. They are reliable and address various local and international issues. Amman Message promotes moderation and respect for people of various religions. It promotes a good image about Islam and its moderation. The latter researcher used the content analysis method to analyze Amman Message. He adopted a critical analytical approach. He adopted a historical approach to identify the reasons that led to issuing Amman Message.

Al-Rahamneh and Al-Qudah (2016) aimed to explorethe role of the Jordanian families inpromoting intellectual security among their sons and daughters. They aimed to explore that from the perspective of the students enrolled in Jordanian universities. To meet the study's goals, a thirty-six item questionnaire was used. This questionnaire sheds a light on three areas. These areas are: social, cultural and religious areas. A random sample was selected. It consists from (2700) students. Those students were selected from four public universities (the University of Jordan, Yarmouk University, Moa'ta University and Al-Balqa' Applied University) and three private universities (Amman Al-AhliahUniversity, ZaytoonahUniversity , Jarash University). The study was conducted during the second semester of the academic year (2015/2016). A descriptive analytical approach was adopted. The means of the (social, cultural and religious) areas are high. The mean of the cultural area is ranked first.

Abdullah and Saeed (2016) aimed to explore the attitudes of teachers towards extremism in Pakistan. They conducted their study because terrorist acts were carried in known educational institutions in Pakistan. They conducted interviews with faculty members. They set the interview questions based on the theoretical literature. The validity of the interview questions was checked. Data was collected from 9 faculty members in Pakistan; 3 females and 6 males. Those faculty member vary in terms of culture, environment, classes, and religions. A descriptive approach was adopted. It was found that there are several types of extremism in Pakistani educational institutions from the faculty members' perspective. According to faculty members, the factors that affect extremism include: financial factors, power, and deprivation from rights. They include poor compliance with Islamic principles, and lack of economic opportunities. They include excessiveness in rewarding the ones who possess competencies.

Fatkhova, and Mingazova (2016) aimed to explore the personal traits of extremists and their relationship 
with media among students in Bashkiria, Russia. They adopted a descriptive qualitative approach. They used a survey and conducted interviews. 578 secondary school students were sampled. The sample consists also from 5 experts who are specialized in psychiatry and work in universities in Ufa, Bashkiria. It was found that technological developments facilitated communication. The negative use of the means of communication methods and social media facilitated the spread of extremist ideas.

Al-Es'aidat (2015) aimed to explore the role of Islamic awareness-raising speeches in accordance with the values implied in Amman Message. He adopted an analytical inductive approach. It was found that that Amman Message aims at promoting moderation. Amman Messages is derived from the Islamic principles and encourages people to keep up with global developments. It identifies the role of the scholars specialized in Shariah in promoting a good image for Islam and defending it from attacks. It promotes moderation and tolerance and fights against extremism. It suggests that the scholars specialized in Shariah must promote moderation and tolerance among young Muslims and prevents the spread of extremism among them.

DAVYdov (2015) aimed to explore the reasons of extremism among young people and identify the methods of fighting it based on educational policies. He used a questionnaire. The sample consists from 70 experts in education and fighting against extremism. It was found that the economic reasons are the most significant reasons leading to extremism. Such economic reasons include: unemployment, and low family income. Other reasons may include: the method used for raising up children, impacts of political parties, political bodies and media. They include: getting influenced by other cultures, and the capability to gain money from adopting extremist ideologies, and the poor performance of educational institutions. They include: the need for promoting a culture of tolerance and having a great number of immigrants. Educational institutions must address the reasons leading to extremism. That can be done through promoting knowledge among people. It can be done through promoting social and religion values through media.DAVYdov (2015) found that fighting against extremism requires fighting against unemployment.

Abu Jaber (2014) aimed to explore the role of faculty members in the Islamic University in Gaza in promoting moderation among students. A adopted descriptive approach was adopted. He aimed to propose a vision for activating the role of faculty members in promoting moderation. 333 female and male students were sampled. They were selected from the faculty of Shariah, faculty of law, faculty of education and faculty of engineering. They were chosen through the stratified random sampling method. It was found that the professional academic area is ranked first. The personal area is ranked second. The social cultural area is ranked third.

Hawari (2011) aimed to explore the role of universities in promoting moderation and intellectual security among students in the University of Laghouat in Algeria. To be specific, he aimed to explore the role of faculty members, educational methods and relationship with the local community in such promotion. He adopted a descriptive approach. The sample was chosen randomly. It consists from 400 deans, faculty members and heads of departments. It was found that there is a need for promoting moderation and intellectual security.

Al-Shara' and Al-Belasi (2011) aimed to explore the extent of promoting moderate ideologies by faculty members among students through modern educational methods. They adopted a descriptive approach. They used a twenty-three item questionnaire. The questionnaire forms were distributed to 189 female students. Those students were selected from different departments. They were selected from Irbid University College that is affiliated with Al- Balqa' Applied University (BAU). It was found the extent of promoting moderate ideologies by faculty members among students is moderate. It was found that extent of promoting moderate ideologies by faculty members in the intellectual area is higher than the counterpart extent in the behavioral area.

Al-Bashri (2011) conducted a study in Taibah University. He aimed to explore the role of the university in promoting moderate ideologies among students through Islamic education activities. He identified the significance of university activities, and teenagers' developmental requirements and manifestations. He identified the meaning of adolescence. He adopted descriptive and deductive approaches. It was found that moderation is a life style approach in Muslims' lives. Moderation should manifest through Muslims' ethics, worships and beliefs. Extremism means that one has abandoned Islam. It was found universities have been always playing a significant role throughout ages. It was found that extra-curriculum activities are important. University students can offer society many things. Islamic education provides clear information about Islam and promotes moderation among students through extra-curriculum activities. Such activities meet the students' demands and requirements.

Comment on previous studies and the location of the current study, including:

Previous studies came mixed with its goals, such as the study of Al-Harahsheh (2018), which aimed to clarify the role of King Abdullah II visions in promoting moderation and moderation, and to analyze the conditions that contributed to its formation and to learn how that thought contributed to preserving the security and safety of Jordan, and the Al-Fayez study (2017) Which aimed to get acquainted with the role of Jordanian political discourse in defending the centrality of Islam (Amman Message as a Model, and the Women's Study) 2015), which aimed this study to explain the general characteristics of Islamic educational discourse, in light of the 
contents of Amman's message quoted from the eternal message of Islam represented by moderation, moderation and realism The stability, flexibility in keeping pace with the developments and developments of the age and human globalism, and the study of Abu Jabr (2014), which aimed to identify the role of faculty members at the Islamic University of Gaza in promoting the principle of moderation in their students and ways to activate it, and the Hawari study (2011), which aimed to identify the role of universities In promoting the principle of moderation and intellectual security for students at the University of Laghouat in Algeria, and the study of Sharia and Balaasi (2011) which aimed to identify the extent of the professor's adoption For intermediate features, and the Al-Muhammady Study, 2018, which explored the role of universities and schools in dealing with the phenomenon of extremism in Malaysia, and the study of Abdullah and Saeed, 2016, which aimed to explore the ideas of university teachers about extremism in education in Pakistan.

The current study is distinguished from previous studies in its handling of the topic of intermediate thought, and enhancing the role of Jordanian public universities in its development and promotion of its students based on (Amman Message), which is the topic of societies most in need in this time as well as this study is distinguished by different time and place, as well as to allocate colleges Scientific and human in this study.

This study is in agreement with Abu Jabr (2014) and Al-Hawari (2011) in its discussion of the role of universities in promoting moderate thought among students, and with the study of Al-Faiz (2018) and AlSaeedat (2017) and Al-Harahsheh (2015) in highlighting the contents of the Amman Message, and also agreed with a study Al-Sharaa and Bilassi in the role of universities in the field of university professor, where it came to a medium degree, and this study differs with previous studies in terms of time and place, where this study addressed the students of official Jordanian universities in three regions: in the north, center and south, while the study population was in studies The previous one is different, and just as this study agreed with many studies that recommended the necessity of promoting and developing the intermediate thought of its students, and the urgent need for it, just as the study agreed with some studies in the methodology of the study, which is the descriptive approach that fits such studies, such as the Abu Jabr study The Sharia, Balaassi, and Hawari, as the result of the study agreed with several studies on the need to pay attention to the moderate moderate thought that we desperately need in our time.

\section{Study methodology}

To achieve the objectives of the study, the descriptive survey method based on the use of the quantitative approach is used to collect the necessary data from the study sample, where quantitative data was collected using the questionnaire for students in Jordanian public universities through the following stages:

\section{Study population and sample}

It will consist of Jordanian university students, who numbered $(2010,4)$ thousands of male and female students, according to statistics issued by the Ministry of Higher Education, (2019). The study sample was chosen from the University of Jordan, Mu'tah University, and Yarmouk University, and by (400) male and female students.

\section{Table (1) the Sample}

\begin{tabular}{|l|l|l|l|}
\hline Variables & Variable levels & Repetition & Percentage \\
\hline Gender & Male & 204 & $51 \%$ \\
\cline { 2 - 4 } & Female & 196 & $49 \%$ \\
\hline \multirow{4}{*}{ Unilege } & Scientific & 258 & $65 \%$ \\
\cline { 2 - 4 } & Humanities colleges & 142 & $36 \%$ \\
\hline \multirow{5}{*}{ academic year } & University of Jordan & 196 & $49 \%$ \\
\cline { 2 - 4 } & Yarmouk & 94 & $24 \%$ \\
\cline { 2 - 4 } & Mutah & 110 & $28 \%$ \\
\hline \multirow{5}{*}{ Academic level } & First year & 98 & $25 \%$ \\
\cline { 2 - 4 } & Second Year & 129 & $32 \%$ \\
\cline { 2 - 4 } & Third Year & 88 & $22 \%$ \\
\cline { 2 - 4 } & the fourth year & 85 & $21 \%$ \\
\hline Cumulative average & Bachelor & 347 & $87 \%$ \\
\cline { 2 - 4 } & Postgraduate & 53 & $13 \%$ \\
\cline { 2 - 4 } & Excellent & 91 & $23 \%$ \\
\cline { 2 - 4 } & very good & 144 & $36 \%$ \\
\cline { 2 - 4 } & good & 123 & $31 \%$ \\
\cline { 2 - 4 } & Acceptable & 42 & $11 \%$ \\
\hline & Total & 400 & $100 \%$ \\
\hline
\end{tabular}




\section{Study Instrument}

To achieve the goals of the study, and after reviewing the theoretical literature and previous studies related to the topic of intermediate thought and its development among students based on the study of Al-Harahsheh (2018) and the study of Al-Fayez (2017) and the study of Abu Jabr (2014) and the study (2028, AL-Muhammad), and provide the expertise of some specialists in The origins of education, the researchers designed the study tool, which dealt with a measure of the reality of the role of Jordanian universities in the promotion and development of intermediate thought among its students, as the target group of the study, and the future of the nation in protecting the homelands from terrorist ideas, and the questionnaire consisted of four areas distributed as follows) The faculty, by 13 paragraphs) and the field of students, by 9 paragraphs), (the field of student union, by 7 paragraphs) and (the field of university activities, by 11 paragraphs).

\section{Validate the study Instrument}

To ensure the validity of the study tool, the researchers used Validity Content, by presenting them to 10 arbitrators, members of the teaching staff at the University of Jordan, with experience and specialization, to express their observations in terms of determining the degree of suitability of the paragraphs and their comprehensiveness to measure the field in which they were received There are those paragraphs, the degree of affiliation of these paragraphs to the field in which they were mentioned, the degree of clarity of the paragraphs, their linguistic and grammatical integrity, and a statement of the proposed amendments to the paragraphs, and an agreement $(80 \%)$ of the arbitrators' observations was adopted indicating the sincerity of the paragraph, and on that basis the observations were adopted and the paragraphs were modified in light of it, and accordingly it became The number of paragraphs 40 paragraphs.

\section{The stability of the study Instrument}

To verify the stability of the instrument, the researchers calculated the stability factor for the reality and importance of the role of Jordanian universities in the promotion and development of contemporary thought for their students, and the Cronbach's Alpha formula was used to extract the internal consistency coefficient for each field of study. To verify the stability of the scale, the stability factor was extracted the internal consistency method using the Cronbach alpha equation and the following table shows these results:

Table (2)

Reliability coefficients extracted by internal consistency method using the Alpha Cronbach equation for the scale

\begin{tabular}{|l|l|l|}
\hline No. & Area & Internal consistency \\
\hline $\mathbf{1}$ & Faculty members & $\mathbf{0 . 8 4 2}$ \\
\hline $\mathbf{2}$ & Students & $\mathbf{0 . 8 5 0}$ \\
\hline $\mathbf{3}$ & Students' Union & $\mathbf{0 . 8 8 3}$ \\
\hline $\mathbf{4}$ & University activities & $\mathbf{0 . 9 0 2}$ \\
\hline & The scale as a whole & $\mathbf{0 . 9 4 9}$ \\
\hline
\end{tabular}

Table (2) shows that the total stability coefficient of the scale of roles was (0.949), and the values of the stability coefficients extracted by the internal consistency method for the sub-domains ranged between $(0.842$ and 0.902 ), which are high and indicate the stability of the scale.

\section{Statistical processing}

Statistical treatments for data in this study were conducted using the Statistical Package for Social Sciences (SPSS), as follows:

- To answer the first study question: What is the reality of the role of Jordanian universities in enhancing the intermediate thinking of their students from their point of view, the arithmetic mean and standard deviations were used for male and female students' responses using the statistical package (SPSS).

- To answer the second question: On the presence of statistically significant differences at the level $(5=\mathrm{a} 0,0)$ in the responses of students in the reality of the role of Jordanian universities for the middle thought due to the gender variable, college, university, academic average, academic year, and academic level, averages were used Computations, standard deviations, multiple-contrast analysis, and Scheffe test for dimensional comparisons using the statistical package (Spss).

\section{The results of the study and its discussion}

The first question: What is the reality of the role of Jordanian universities in the practice of fostering moderate thinking based on the Amman Message from their students from their point of view?

To answer this question, arithmetic mean, standard deviations, and the degree of reality of the role of universities practiced to promote intermediate thinking based on the Amman Message were extracted from their students from their point of view, and the following table shows the results: 
Table (3)

Arithmetic mean, Standard Deviations, and Degree of Reality of the Role of Jordanian Universities Practicing to Promote Moderate Thought Based on Their Students' Point of View in Descending Order

\begin{tabular}{|l|l|l|l|l|l|l|l|}
\hline Rank & No. & Area & $\begin{array}{l}\text { Arithmetic } \\
\text { mean }\end{array}$ & $\begin{array}{l}\text { standard } \\
\text { deviation }\end{array}$ & $\begin{array}{l}\text { T } \\
\text { value }\end{array}$ & $\begin{array}{l}\text { Significance } \\
\text { level }\end{array}$ & Level \\
\hline $\mathbf{1}$ & $\mathbf{1}$ & Faculty members & $\mathbf{3 . 4 8}$ & $\mathbf{0 . 6 7 3}$ & $\mathbf{1 4 . 1 6 7}$ & $\mathbf{0 . 0 0 0 *}$ & Moderate \\
\hline $\mathbf{2}$ & $\mathbf{2}$ & Students & $\mathbf{3 . 4 5}$ & $\mathbf{0 . 8 0 0}$ & $\mathbf{1 1 . 3 1 2}$ & $\mathbf{0 . 0 0 0 *}$ & Moderate \\
\hline $\mathbf{3}$ & $\mathbf{3}$ & Students' Union & $\mathbf{3 . 3 9}$ & $\mathbf{0 . 9 2 6}$ & $\mathbf{8 . 3 2 7}$ & $\mathbf{0 . 0 0 0 *}$ & Moderate \\
\hline $\mathbf{4}$ & $\mathbf{4}$ & $\begin{array}{l}\text { University } \\
\text { activities }\end{array}$ & $\mathbf{3 . 3 2}$ & $\mathbf{0 . 8 3 4}$ & $\mathbf{7 . 5 6 1}$ & $\mathbf{0 . 0 0 0 *}$ & Moderate \\
\hline & $\begin{array}{l}\text { Overall mean of } \\
\text { roles }\end{array}$ & $\mathbf{3 . 4 1}$ & $\mathbf{0 . 6 7 4}$ & $\mathbf{1 2 . 1 5 8}$ & $\mathbf{0 . 0 0 0 *}$ & Moderate \\
\hline
\end{tabular}

* Statistically significant at the significance level 0.05

Table (3) shows that the average for the degree of reality of the role of Jordanian universities practicing to enhance the middle thought based on the Amman Message when its students from their viewpoint reached (3.41) and an average degree, where the field (faculty members) came first with the highest arithmetic mean (3.48) And with an average degree, followed by the field of (students) with an average score of (3.45) and an average degree, then the field of (student union) with an average score of (3.39) and an average degree, while the field of (university activities) came in the last rank with the lowest average score (3.32) and Moderate degree.

The table shows that the value of " $\mathrm{T}$ " for the field of the role of faculty members reached (14.167), for the field of students reached (11.312), for the field of student union reached (8.327) and for the field of university activities reached (7.561), and for the total degree of roles reached (12.158), which are values Statistically significant at the level of significance 0.05 , that is, there are statistically significant differences between all averages of fields, the total degree of the scale and the degree of cutting (3). All differences came to domains and the overall degree of the scale with an arithmetic mean greater than (3).

The results showed that the degree of the reality of the role of Jordanian universities practicing to promote the moderate thought based on the Amman Message among its students came at a moderate degree, as it reached $(3,41)$ and this is due to the moderate moderate thought that Jordan pursues in all fields, and the document based on the moderate Hashemite thought that is taken from the Amman Message It is the Message of Islam as a methodology, and the faculty member came with the highest arithmetic mean, with an average degree $(3,48)$, followed by the field of students with an arithmetic average $(3,45)$, and then the Students Union with an arithmetic mean $(3,39)$ and university activities came with the last degree with the lowest arithmetic mean $(3,32)$, which calls for the promotion of moderate thinking among students through the university professor in the first place, where he has a great responsibility and activation of activities and student union.

Below is a breakdown of the areas and roles:

First: faculty members

Table (4).Arithmetic mean, Standard Deviations, and Degree of Reality of the Role of Jordanian Universities Practicing to Promote Moderate Thought Based on the Amman Message when Students Requested from Their Viewpoint of the Field of Teaching Staff Members in Descending Order

\begin{tabular}{|c|c|c|c|c|c|c|c|}
\hline Rank & No. & Paragraph & $\begin{array}{l}\text { Arithmetic } \\
\text { mean }\end{array}$ & $\begin{array}{l}\text { standard } \\
\text { deviation }\end{array}$ & $\begin{array}{l}\text { T } \\
\text { value }\end{array}$ & $\begin{array}{l}\text { Significance } \\
\text { level }\end{array}$ & Level \\
\hline 1 & 1 & $\begin{array}{l}\text { The faculty member provides } \\
\text { moderate moderate thought }\end{array}$ & 3.80 & 1.052 & 14.905 & $0.000 *$ & High \\
\hline 2 & 2 & $\begin{array}{l}\text { Adopts moderate opinions in a } \\
\text { scientific and objective manner }\end{array}$ & 3.71 & 0.904 & 15.766 & $0.000 *$ & High \\
\hline 3 & 8 & $\begin{array}{l}\text { It encourages meaningful } \\
\text { discussion and effective } \\
\text { dialogue within the lecture hall }\end{array}$ & 3.66 & 1.103 & 12.013 & $0.000 *$ & Moderate \\
\hline 4 & 7 & $\begin{array}{l}\mathrm{He} \text { is keen to discuss all } \\
\text { opinions and trends objectively } \\
\text { and with respect }\end{array}$ & 3.65 & 1.089 & 11.890 & $0.000 *$ & Moderate \\
\hline 5 & 12 & 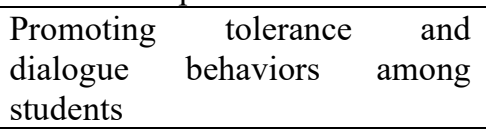 & 3.61 & 1.082 & 11.324 & $0.000 *$ & Moderate \\
\hline 6 & 6 & $\begin{array}{l}\text { It addresses extremist ideas in an } \\
\text { objective and calm manner }\end{array}$ & 3.56 & 1.125 & 9.960 & $0.000 *$ & Moderate \\
\hline 7 & 4 & $\begin{array}{l}\text { Subject subjects raised in his } \\
\text { lectures to revelation and reason }\end{array}$ & 3.53 & 1.092 & 9.662 & $0.000 *$ & Moderate \\
\hline
\end{tabular}




\begin{tabular}{|c|c|c|c|c|c|c|c|}
\hline Rank & No. & Paragraph & $\begin{array}{l}\text { Arithmetic } \\
\text { mean }\end{array}$ & $\begin{array}{l}\text { standard } \\
\text { deviation }\end{array}$ & $\begin{array}{l}\mathrm{T} \\
\text { value }\end{array}$ & $\begin{array}{l}\text { Significance } \\
\text { level }\end{array}$ & Level \\
\hline 8 & 5 & $\begin{array}{l}\text { It helps students build their } \\
\text { judgments based on logical } \\
\text { evidence }\end{array}$ & 3.51 & 1.148 & 8.884 & $0.000 *$ & Moderate \\
\hline 9 & 3 & $\begin{array}{l}\text { He distanced himself from an } \\
\text { extremist interpretation of legal } \\
\text { texts and evidence }\end{array}$ & 3.42 & 1.567 & 5.361 & $0.000 \%$ & Moderate \\
\hline 10 & 11 & $\begin{array}{l}\text { Explains Islamic moderation as } \\
\text { contained in the Amman } \\
\text { Message }\end{array}$ & 3.39 & 1.188 & 6.565 & $0.000 *$ & Moderate \\
\hline 11 & 10 & $\begin{array}{l}\text { He avoids prejudging his } \\
\text { students }\end{array}$ & 3.37 & 1.126 & 6.619 & $0.000 *$ & Moderate \\
\hline 12 & 13 & $\begin{array}{l}\text { Presenting models of Islamic } \\
\text { leaders who contributed to } \\
\text { building Islamic civilization }\end{array}$ & 3.20 & 1.313 & 3.009 & 0.003* & Moderate \\
\hline 13 & 9 & $\begin{array}{l}\text { Terrorist issues are under } \\
\text { discussion to reveal the } \\
\text { students 'directions }\end{array}$ & 2.79 & 1.352 & -3.144 & $0.002 *$ & Moderate \\
\hline
\end{tabular}

* Statistically significant at the significance level 0.05

Table (4) shows that the arithmetic mean, the standard deviations, and the degree of reality of the role of Jordanian universities practicing to enhance the intermediate thought based on the Amman Message when its students from their point of view for the field of faculty members ranged between (2.79 and 3.80), where the paragraph came (the faculty member provides thought Moderately moderate (at the first rank with the highest arithmetic mean (3.80) and with a high degree, while the paragraph (terrorist issues are subject to discussion to reveal students 'tendencies) came in the last rank with the lowest arithmetic mean (2.79) and with an average degree.

The table shows that the values of " $\mathrm{T}$ " ranged between (-3.14 and 15.766), and there was a statistically significant function for all paragraphs, meaning that there are statistically significant differences between all paragraphs and the degree of severity (3), and the differences for all paragraphs (1-13) came in favor of Paragraphs excluding paragraph (9), with an average arithmetic mean higher than the degree of cutting (3).

Differences came in favor of the degree of cutting for paragraph (9), where the mean of the degree of cutting (3) was higher than the mean for paragraph 9 (2.79).

The researcher attributes this to the fact that the university professor in Jordanian universities is distinguished by moderate and moderate thought and presents ideas in objective ways as a result of the general atmosphere that prevails in Jordan, which pursues a moderate policy at all local, regional and international levels that distinguishes it from other countries and also the presence of a wise moderate leadership that pursues the linked middle thought.

Table (5)

Arithmetic mean, Standard Deviations, and Degree of Reality of the Role of Jordanian Universities Practicing to Promote Moderate Thought Based on Amman MessageWhen Students See it from Their Viewpoint of Student Field in Descending Order

\begin{tabular}{|c|c|c|c|c|c|c|c|}
\hline Rank & No. & Paragraph & $\begin{array}{l}\text { Arithmetic } \\
\text { mean }\end{array}$ & $\begin{array}{l}\text { standard } \\
\text { deviation }\end{array}$ & $\begin{array}{l}T \\
\text { value }\end{array}$ & $\begin{array}{l}\text { Significance } \\
\text { level }\end{array}$ & Level \\
\hline 1 & 1 & $\begin{array}{l}\text { The university promotes } \\
\text { concepts of tolerance and } \\
\text { moderation among students }\end{array}$ & 3.66 & 1.243 & 10.540 & 0.000* & Moderate \\
\hline 2 & 6 & $\begin{array}{l}\text { Encouraging students towards } \\
\text { collaborative work to establish } \\
\text { the importance of the group }\end{array}$ & 3.60 & 1.117 & 10.741 & 0.000* & Moderate \\
\hline 3 & 4 & $\begin{array}{l}\text { It educates students about the } \\
\text { dangers of drugs, alcohol and } \\
\text { smoking on human thought }\end{array}$ & 3.55 & 1.177 & 9.387 & 0.000* & Moderate \\
\hline 4 & 2 & $\begin{array}{l}\text { Adopts a moderate integrated } \\
\text { student personality in thinking } \\
\text { and behavior }\end{array}$ & 3.51 & 1.033 & 9.823 & $0.000^{*}$ & Moderate \\
\hline
\end{tabular}




\begin{tabular}{|l|l|l|l|l|l|l|l|}
\hline Rank & No. & Paragraph & $\begin{array}{l}\text { Arithmetic } \\
\text { mean }\end{array}$ & $\begin{array}{l}\text { standard } \\
\text { deviation }\end{array}$ & $\begin{array}{l}\text { T } \\
\text { value }\end{array}$ & $\begin{array}{l}\text { Significance } \\
\text { level }\end{array}$ & Level \\
\hline $\mathbf{5}$ & $\mathbf{3}$ & $\begin{array}{l}\text { It seeks to integrate students } \\
\text { with the local community } \\
\text { through volunteer work }\end{array}$ & $\mathbf{3 . 4 9}$ & $\mathbf{1 . 1 9 9}$ & $\mathbf{8 . 0 8 8}$ & $\mathbf{0 . 0 0 0 *}$ & Moderate \\
\hline $\mathbf{6}$ & $\mathbf{5}$ & $\begin{array}{l}\text { Students warn of the dangers } \\
\text { of extremist thought }\end{array}$ & $\mathbf{3 . 4 3}$ & $\mathbf{1 . 2 6 1}$ & $\mathbf{6 . 8 6 1}$ & $\mathbf{0 . 0 0 0 *}$ & Moderate \\
\hline $\mathbf{7}$ & $\mathbf{9}$ & $\begin{array}{l}\text { Students are educated about } \\
\text { the importance of moderate } \\
\text { thought in stabilizing society }\end{array}$ & $\mathbf{3 . 4 2}$ & $\mathbf{1 . 1 6 7}$ & $\mathbf{7 . 1 9 8}$ & $\mathbf{0 . 0 0 0 *}$ & Moderate \\
\hline $\mathbf{8}$ & $\begin{array}{l}\text { It educates students about the } \\
\text { danger of moving away from } \\
\text { the teachings of Islam to the } \\
\text { individual and society }\end{array}$ & $\mathbf{3 . 2 6}$ & $\mathbf{1 . 2 3 0}$ & $\mathbf{4 . 2 6 9}$ & $\mathbf{0 . 0 0 0 *}$ & Moderate \\
\hline $\mathbf{9}$ & $\begin{array}{l}\text { You invest free time for } \\
\text { students with meaningful } \\
\text { activities }\end{array}$ & $\mathbf{3 . 1 6}$ & $\mathbf{1 . 2 2 9}$ & $\mathbf{2 . 5 2 3}$ & $\mathbf{0 . 0 1 2 *}$ & Moderate \\
\hline
\end{tabular}

\section{* Statistically significant at the significance level 0.05}

\section{Second: Student field:}

Table (5) shows that the arithmetic mean, the standard deviations, and the degree of reality of the role of Jordanian universities practicing to foster an intermediate thought based on the Amman Message when students demanded from their viewpoint of the student field ranged between (3.16 and 3.66), where the paragraph came (the university promotes the concepts of tolerance and moderation between Students), at the first rank, with the highest arithmetic mean (3.66) and an average degree, while the paragraph (you invest free time for students with meaningful activities) came at the last rank with the lowest arithmetic mean (3.16) and an average degree.

The table shows that the values of "T" ranged between (2.523 and 10.741) and statistically significant for all paragraphs, that is, there are statistically significant differences between all paragraphs and the degree of severity 3 ) and the differences for all paragraphs (1-9) in favor of the paragraphs came with a higher arithmetic mean from the degree of cutting (3).

The researcher attributes this result to the fact that students in Jordanian universities enjoy an atmosphere of moderation in thought and behavior, and the university needs to promote such behavior, because of the importance of this topic, especially at the present time, and that the university's role is to increase awareness of its students, and not neglect this aspect, and the researcher recommends Universities and curricula increase interest in this subject because of its extreme importance in forming the normal, moderate personality of students. Third: Student Union

Table (6): Arithmetic mean, Standard Deviations, and Degree of Reality of the Role of Jordanian Universities Practicing to Promote Moderate Thought Based on the Amman Message When Students See it from Their Viewpoint of the Student Union Field Descending Order

\begin{tabular}{|l|l|l|l|l|l|l|l|}
\hline Rank & No. & Paragraph & $\begin{array}{l}\text { Arithmetic } \\
\text { mean }\end{array}$ & $\begin{array}{l}\text { standard } \\
\text { deviation }\end{array}$ & $\begin{array}{l}\text { T } \\
\text { value }\end{array}$ & $\begin{array}{l}\text { Significance } \\
\text { level }\end{array}$ & Level \\
\hline $\mathbf{1}$ & $\mathbf{1}$ & $\begin{array}{l}\text { The Student Union adopts } \\
\text { activities that foster cooperation } \\
\text { between the student body and } \\
\text { the university administration }\end{array}$ & $\mathbf{3 . 7 0}$ & $\mathbf{1 . 2 1 8}$ & $\mathbf{1 1 . 4 9 4}$ & $\mathbf{0 . 0 0 0 *}$ & High \\
\hline $\mathbf{2}$ & $\mathbf{2}$ & $\begin{array}{l}\text { Perform activities that contribute } \\
\text { to building the student' } \\
\text { integrated, conscious personality }\end{array}$ & $\mathbf{3 . 4 6}$ & $\mathbf{1 . 1 0 5}$ & $\mathbf{8 . 3 6 9}$ & $\mathbf{0 . 0 0 0 *}$ & Moderate \\
\hline $\mathbf{3}$ & $\mathbf{4}$ & $\begin{array}{l}\text { Promotes belonging to the } \\
\text { country through group activities }\end{array}$ & $\mathbf{3 . 4 5}$ & $\mathbf{1 . 1 8 8}$ & $\mathbf{7 . 6 1 8}$ & $\mathbf{0 . 0 0 0 *}$ & Moderate \\
\hline $\mathbf{4}$ & $\mathbf{6}$ & $\begin{array}{l}\text { It develops the spirit of } \\
\text { neighborhood and respect for } \\
\text { opinion and other opinion }\end{array}$ & $\mathbf{3 . 3 9}$ & $\mathbf{1 . 1 6 9}$ & $\mathbf{6 . 6 7 3}$ & $\mathbf{0 . 0 0 0 *}$ & Moderate \\
\hline $\mathbf{5}$ & $\mathbf{P}$ & $\begin{array}{l}\text { Promotes university affiliation } \\
\text { through activities that stimulate } \\
\text { giving }\end{array}$ & $\mathbf{3 . 3 6}$ & $\mathbf{1 . 1 7 2}$ & $\mathbf{6 . 1 8 4}$ & $\mathbf{0 . 0 0 0 *}$ & Moderate \\
\hline $\mathbf{6}$ & $\begin{array}{l}\text { It reinforces the concepts of } \\
\text { Oman's Message calling for } \\
\text { moderation through activities }\end{array}$ & $\mathbf{3 . 3 0}$ & $\mathbf{1 . 3 2 9}$ & $\mathbf{4 . 5 5 3}$ & $\mathbf{0 . 0 0 0 *}$ & Moderate \\
\hline
\end{tabular}




\begin{tabular}{|l|l|l|l|l|l|l|l|}
\hline Rank & No. & Paragraph & $\begin{array}{l}\text { Arithmetic } \\
\text { mean }\end{array}$ & $\begin{array}{l}\text { standard } \\
\text { deviation }\end{array}$ & $\begin{array}{l}\text { T } \\
\text { value }\end{array}$ & $\begin{array}{l}\text { Significance } \\
\text { level }\end{array}$ & Level \\
\hline $\mathbf{7}$ & $\mathbf{5}$ & $\begin{array}{l}\text { It discards racism and regional } \\
\text { activities }\end{array}$ & $\mathbf{3 . 0 3}$ & $\mathbf{1 . 2 6 2}$ & $\mathbf{0 . 4 7 5}$ & $\mathbf{0 . 6 3 5}$ & Moderate \\
\hline
\end{tabular}

* Statistically significant at the significance level 0.05

Table (6) shows that the arithmetic mean, the standard deviations, and the degree of reality of the role of Jordanian universities practicing to foster an intermediate thought based on the Amman Message when students demanded from their viewpoint of the field of student union ranged between (3.03 and 3.70), where the paragraph came (the student union adopts activities that enhance cooperation Between the student body and the university administration) at the first rank with the highest arithmetic mean (3.70) and with a high degree, while the paragraph (carrying out activities that reject racism and regionalism) came at the last rank with the lowest arithmetic mean (3.03) and an average degree.

The table shows that the values of "T" ranged between $(0.475$ and 11.494$)$, and a statistic function came for all paragraphs except for paragraph (5), meaning that there are statistically significant differences between all paragraphs and the degree of cutting (3) with the exception of paragraph (5) and the differences came For all paragraphs (1-7)

In favor of paragraphs with an average arithmetic higher than the degree of cutting (3)

The table shows that the value of " $\mathrm{T}$ " for paragraph (5) was (0.475), which is a statistically insignificant value at the significance level of 0.05 , meaning that there are no statistically significant differences between the average of paragraph (5) and the degree of cutting (3).

The researcher attributes this result, to the development of this field in our Jordanian universities, which calls for an intensification of the role of the Student Union, in communication between the university and students and the development of this moderate intermediate thought, and this requires the establishment of a union that represents students properly, and provide the necessary support to carry out this responsibility.

Fourth: University activities:

Table (7): Arithmetic mean, Standard Deviations, and Degree of Reality of the Role of Jordanian Universities Practiced to Promote Moderate Thought Based on the Amman Message when requested by their students from their viewpoint of the field of university activities in descending order

\begin{tabular}{|c|c|c|c|c|c|c|c|}
\hline Rank & No. & Paragraph & $\begin{array}{l}\text { Arithmetic } \\
\text { mean }\end{array}$ & $\begin{array}{l}\text { standard } \\
\text { deviation }\end{array}$ & $\begin{array}{l}\mathrm{T} \\
\text { value }\end{array}$ & $\begin{array}{l}\text { Significance } \\
\text { level }\end{array}$ & Level \\
\hline 1 & 2 & $\begin{array}{l}\text { It seeks to conduct activities } \\
\text { that call for cultural exchange } \\
\text { between students }\end{array}$ & 3.70 & 1.191 & 10.113 & $0.000 *$ & High \\
\hline 2 & 3 & $\begin{array}{l}\text { It seeks to involve the largest } \\
\text { number of students in the } \\
\text { dialogue activities }\end{array}$ & 3.54 & 1.073 & 6.487 & $0.000 *$ & Moderate \\
\hline 3 & 10 & $\begin{array}{l}\text { Dialogue seminars are held to } \\
\text { promote moderate thought } \\
\text { among students }\end{array}$ & 3.36 & 1.118 & 4.756 & $0.000 *$ & Moderate \\
\hline 4 & 8 & $\begin{array}{l}\text { Adopts an invitation to } \\
\text { political and security figures } \\
\text { to talk about the dangers of } \\
\text { deviant thought }\end{array}$ & 3.28 & 1.188 & 4.770 & $0.000 *$ & Moderate \\
\hline 5 & 5 & $\begin{array}{l}\text { Using the values of the } \\
\text { Islamic religion that advocates } \\
\text { moderation in student } \\
\text { activities }\end{array}$ & 3.28 & 1.164 & 4.498 & $0.000 *$ & Moderate \\
\hline 6 & 4 & $\begin{array}{l}\text { In the university's corners and } \\
\text { entrances, phrases of } \\
\text { moderation and moderation } \\
\text { are displayed }\end{array}$ & 3.27 & 1.189 & 4.379 & $0.000 *$ & Moderate \\
\hline 7 & 6 & $\begin{array}{l}\text { Adopts activities that lead to } \\
\text { emotional control and self- } \\
\text { control }\end{array}$ & 3.26 & 1.199 & 3.559 & $0.000 *$ & Moderate \\
\hline 8 & 9 & $\begin{array}{l}\text { Partnering with the local } \\
\text { community to spread the } \\
\text { values of moderation }\end{array}$ & 3.22 & 1.222 & 3.734 & $0.000 *$ & Moderate \\
\hline
\end{tabular}




\begin{tabular}{|l|l|l|l|l|l|l|l|}
\hline $\mathbf{9}$ & $\mathbf{1 1}$ & $\begin{array}{l}\text { There are activities that show } \\
\text { the impact of student violence } \\
\text { on moderate thought }\end{array}$ & $\mathbf{3 . 2 1}$ & $\mathbf{1 . 1 3 8}$ & $\mathbf{3 . 1 1 1}$ & $\mathbf{0 . 0 0 2 *}$ & Moderate \\
\hline $\mathbf{1 0}$ & $\mathbf{7}$ & $\begin{array}{l}\text { She adopts an invitation to } \\
\text { theologians to speak of } \\
\text { moderate thought }\end{array}$ & $\mathbf{1}$ & $\begin{array}{l}\text { The university conducts } \\
\text { various activities that foster } \\
\text { and develop moderate } \\
\text { moderate thought among } \\
\text { students }\end{array}$
\end{tabular}

* Statistically significant at the significance level 0.05

Table (7) shows that the arithmetic mean, standard deviations, and the degree of reality of the role of Jordanian universities practicing to promote intermediate thinking based on the Amman Messagewhen its students from their viewpoint of the field of university activities ranged between (3.15 and 3.70), where the paragraph (seeking to do activities calling for cultural exchange) Among students), at the first rank, with the highest arithmetic mean (3.70) and with a high degree, while the paragraph came (the university undertakes various activities that promote and develop moderate moderate thought among students) at the last rank with the lowest arithmetic mean (3.15) and with an average degree.

The table shows that the values of " $T$ " ranged between (2.549 and 11.755) and statistically significant for all paragraphs, that is, there are statistically significant differences between all paragraphs and the degree of severity (3) and the differences for all paragraphs (1-11) in favor of the paragraphs came with an average. Higher than the cutting grade (3).

Through this result, it is clear that the reality practiced to enhance the role of Jordanian universities in enhancing the middle thought of their students came with a medium degree, and this result is due to the presence of Jordanian universities that are interested and invest in their students and develop a balanced student personality, in terms of the presence of the university professor who plays the role and students, and university activities That contribute to the promotion of positive behaviors, and despite this, this result requires serious work to develop and promote the moderate and moderate thought pursued by students, the university and the university professor, given the spread of destructive, extremist and abnormal ideas, which seek to destroy students 'minds and develop obscurantist thought in their minds, and this is what This study sought to protect our student and youth children from the distortions that threaten their future and that of their societies. As we have noted in the table, the university professor obtained the first degree with the highest arithmetic mean, and this result is attributed to his presentation of moderate moderate thought, as this paragraph won the highest degree and the excellence of the educational staff in Jordanian universities, and the educational and scientific level reached by the result of the scientific environment that education reached in Jordan. This was followed by the second-class field of students, which is attributed to the general atmosphere in universities, which encourages moderation and rejects extremism and destructive ideas. And the role of the university in promoting the concepts of tolerance and moderation among students, as this paragraph has obtained the highest arithmetic mean and a medium degree.

Results related to the second question: Are there statistically significant differences at the level $(0.0=0.05)$ in the responses of Jordanian university students in the role of universities in the development of intermediate thought due to the variable, college, university, academic year, and the GPA?

To answer this question, arithmetic averages and standard deviations were extracted from the responses of Jordanian university students in the role of universities in developing intermediate thought, according to the variables, college, university, and school year, and the GPA and the following table (8) between these averages:

Arithmetic averages and standard deviations for the responses of Jordanian university students in the role of universities in developing the medieval thought of sub-domains according to the variables of the college, university, and academic year, and the cumulative average, which came to the college graduate with an average degree and in the interest of human colleges (3.55) and for the university variable and in the interests of the University of Jordan and an arithmetic average ( 3.53) and for the first academic year with an average of (3.61) and for the GPA very good and with an average of (3.53) 
Table (8)

\begin{tabular}{|c|c|c|c|c|c|}
\hline Variable & Area & Variable level & No. & Mean & $\begin{array}{l}\text { standard } \\
\text { deviation }\end{array}$ \\
\hline \multirow[t]{8}{*}{ College } & \multirow[t]{2}{*}{ Faculty members } & Scientific & 258 & 3.36 & 0.690 \\
\hline & & Humanities colleges & 142 & 3.69 & 0.584 \\
\hline & \multirow[t]{2}{*}{ Students } & Scientific & 258 & 3.37 & 0.788 \\
\hline & & Humanities colleges & 142 & 3.60 & 0.802 \\
\hline & \multirow[t]{2}{*}{ Students' Union } & Scientific & 258 & 3.32 & 0.922 \\
\hline & & Humanities colleges & 142 & 3.50 & 0.926 \\
\hline & \multirow[t]{2}{*}{ University activities } & Scientific & 258 & 3.28 & 0.857 \\
\hline & & Humanities colleges & 142 & 3.39 & 0.790 \\
\hline \multirow[t]{12}{*}{ the University } & \multirow[t]{3}{*}{ Faculty members } & University of Jordan & 196 & 3.61 & 0.627 \\
\hline & & Yarmouk & 94 & 3.43 & 0.710 \\
\hline & & Mutah & 110 & 3.29 & 0.679 \\
\hline & \multirow[t]{3}{*}{ Students } & University of Jordan & 196 & 3.54 & 0.751 \\
\hline & & Yarmouk & 94 & 3.56 & 0.699 \\
\hline & & Mutah & 110 & 3.20 & 0.907 \\
\hline & \multirow[t]{3}{*}{ Students' Union } & University of Jordan & 196 & 3.57 & 0.809 \\
\hline & & Yarmouk & 94 & 3.50 & 0.924 \\
\hline & & Mutah & 110 & 2.97 & 0.997 \\
\hline & \multirow[t]{3}{*}{ University activities } & University of Jordan & 196 & 3.42 & 0.772 \\
\hline & & Yarmouk & 94 & 3.43 & 0.819 \\
\hline & & Mutah & 110 & 3.03 & 0.893 \\
\hline \multirow[t]{16}{*}{ academic year } & \multirow[t]{4}{*}{ Faculty members } & First year & 98 & 3.73 & 0.612 \\
\hline & & Second Year & 129 & 3.51 & 0.667 \\
\hline & & Third Year & 88 & 3.51 & 0.627 \\
\hline & & the fourth year & 85 & 3.08 & 0.635 \\
\hline & \multirow[t]{4}{*}{ Students } & First year & 98 & 3.12 & 0.743 \\
\hline & & Second Year & 129 & 3.53 & 0.785 \\
\hline & & Third Year & 88 & 3.57 & 0.713 \\
\hline & & the fourth year & 85 & 3.02 & 0.827 \\
\hline & \multirow[t]{4}{*}{ Students' Union } & First year & 98 & 3.62 & 0.825 \\
\hline & & Second Year & 129 & 3.43 & 0.897 \\
\hline & & Third Year & 88 & 3.50 & 0.818 \\
\hline & & the fourth year & 85 & 2.92 & 1.036 \\
\hline & \multirow[t]{4}{*}{ University activities } & First year & 98 & 3.45 & 0.788 \\
\hline & & Second Year & 129 & 3.38 & 0.813 \\
\hline & & Third Year & 88 & 3.37 & 0.753 \\
\hline & & the fourth year & 85 & 3.00 & 0.930 \\
\hline \multirow{16}{*}{$\begin{array}{l}\text { Cumulative } \\
\text { average }\end{array}$} & \multirow[t]{4}{*}{ Faculty members } & Excellent & 91 & 3.55 & 0.644 \\
\hline & & very good & 144 & 3.56 & 0.654 \\
\hline & & Good & 123 & 3.38 & 0.691 \\
\hline & & Acceptable & 42 & 3.34 & 0.712 \\
\hline & \multirow[t]{4}{*}{ Students } & Excellent & 91 & 3.37 & 0.848 \\
\hline & & very good & 144 & 3.62 & 0.696 \\
\hline & & Good & 123 & 3.34 & 0.869 \\
\hline & & Acceptable & 42 & 3.39 & 0.740 \\
\hline & \multirow[t]{4}{*}{ Students' Union } & Excellent & 91 & 3.26 & 0.834 \\
\hline & & very good & 144 & 3.52 & 0.931 \\
\hline & & Good & 123 & 3.24 & 0.995 \\
\hline & & Acceptable & 42 & 3.61 & 0.802 \\
\hline & \multirow[t]{4}{*}{ University activities } & Excellent & 91 & 3.31 & 0.834 \\
\hline & & very good & 144 & 3.44 & 0.799 \\
\hline & & Good & 123 & 3.14 & 0.874 \\
\hline & & Acceptable & 42 & 3.42 & 0.772 \\
\hline
\end{tabular}

Table (8) shows the existence of apparent differences in arithmetic mean and standard deviations of the responses of Jordanian university students in the role of universities in developing the average thought of sub- 
domains according to the college, university, and academic year changes, and the cumulative average, and to know the significance of the differences in sub-fields according to study variables Multivariate Test analysis was performed according to the study variables, Table (9) shows this test.

Table (9)

Multivariate Test for the fields of scale of the role of universities in developing intermediate thinking, according to study variables

\begin{tabular}{|l|l|l|l|}
\hline Independent variables & Statistic test hotelling's Trace & "F" Value & Significance level \\
\hline College & 0.034 & 3.331 & $* 0.011$ \\
\hline Independent variables & Statistician test Wilks' Lambda & "F" Value & Significance level \\
\hline University & 0.943 & 2.864 & $* 0.004$ \\
\hline academic year & 0.899 & 3.503 & $* 0.000$ \\
\hline Cumulative average & 0.920 & 2.747 & $* 0.001$ \\
\hline
\end{tabular}

* Statistically significant at the significance level 0.05

Table (9) shows that there are statistically significant differences for the responses of Jordanian university students in the role of universities in developing the medieval thought of sub-domains according to the college, university, and academic year variables, and the GPA, and to know the sources of the differences, a multiple quadratic contrast analysis test (MANOVA WAY 4) was conducted. ), And the following table shows these results:

Table (10)

Multiple quadratic variance analysis of responses to Jordanian university students 'responses to the role of universities in developing intermediate thinking in sub-domains according to study variables

\begin{tabular}{|c|c|c|c|c|c|c|}
\hline Source & Area & $\begin{array}{l}\text { Sum of } \\
\text { squares }\end{array}$ & $\begin{array}{l}\text { Degrees of } \\
\text { freedom }\end{array}$ & $\begin{array}{l}\text { Average } \\
\text { squares }\end{array}$ & $\begin{array}{l}\text { "F" } \\
\text { value }\end{array}$ & $\begin{array}{l}\text { Statistical } \\
\text { significance }\end{array}$ \\
\hline \multirow[t]{4}{*}{ College } & Faculty members & 3.840 & 1 & 3.840 & 9.894 & $.002 *$ \\
\hline & Students & 2.850 & 1 & 2.850 & 5.004 & $.026 *$ \\
\hline & Students' Union & .740 & 1 & .740 & .980 & .323 \\
\hline & University activities & .287 & 1 & .287 & .438 & .508 \\
\hline \multirow{4}{*}{ University } & Faculty members & .708 & 2 & .354 & .912 & .403 \\
\hline & Students & 2.907 & 2 & 1.454 & 2.552 & .079 \\
\hline & Students' Union & 12.818 & 2 & 6.409 & 8.486 & $.000 *$ \\
\hline & University activities & 5.751 & 2 & 2.876 & 4.386 & $.013 *$ \\
\hline \multirow[t]{4}{*}{ academic year } & Faculty members & 12.161 & 3 & 4.054 & 10.444 & $.000 *$ \\
\hline & Students & 11.816 & 3 & 3.939 & 6.914 & $.000 *$ \\
\hline & Students' Union & 11.227 & 3 & 3.742 & 4.955 & $.002 *$ \\
\hline & University activities & 3.880 & 3 & 1.293 & 1.973 & .118 \\
\hline \multirow{4}{*}{$\begin{array}{l}\text { Cumulative } \\
\text { average }\end{array}$} & Faculty members & 2.111 & 3 & .704 & 1.813 & .144 \\
\hline & Students & 6.793 & 3 & 2.264 & 3.975 & $.008 *$ \\
\hline & Students' Union & 9.103 & 3 & 3.034 & 4.018 & $.008 *$ \\
\hline & University activities & 4.723 & 3 & 1.574 & 2.401 & .067 \\
\hline \multirow[t]{4}{*}{ The error } & Faculty members & 151.369 & 390 & .388 & & \\
\hline & Students & 222.153 & 390 & .570 & & \\
\hline & Students' Union & 294.560 & 390 & .755 & & \\
\hline & University activities & 255.717 & 390 & .656 & & \\
\hline \multirow[t]{4}{*}{ Overall } & Faculty members & 180.680 & 399 & & & \\
\hline & Students & 255.062 & 399 & & & \\
\hline & Students' Union & 342.408 & 399 & & & \\
\hline & University activities & 277.782 & 399 & & & \\
\hline
\end{tabular}

* Statistically significant at the level of 0.05

Discussion of the results for the second question: According to the variables in the study:

College variable: First: The field of faculty members and the field of students:

Table (10) shows that the value of "F" value to the field of faculty members according to the college variable (9.894) and the field of students: (5.004) which are statistically significant values at the level of significance 0.05 , that is, there are statistically significant differences for the responses of Jordanian university students in the role Universities in the development of intermediate thought, depending on the variable of the college for the field of faculty members and the field of students. Differences came in favor of human colleges with an average arithmetic higher than scientific.

This is due to the fact that faculty members in human colleges, as a result of their specializations, give the 
student flexibility in the discussion and expansion of social and human subjects, and this role is exercised by faculty members in human colleges more than scientific, because scientific colleges have something of stagnation, and the limited time that The teaching member is not allowed to address topics outside the framework of the lesson, as differences have come in favor of the students 'field, for the same reason that students in human colleges enjoy more time than scientific colleges as a result of the nature of human studies, which allow greater freedom of discussion and expansion in Turning to external events, and because of the nature of the human subjects, which include social and humanitarian topics of interest to the student and the teacher alike.

The field of the Student Union and University Activities: The value of "F" field of the Student Union according to the college variable (0.980) and the field of university activities $(0.438)$, which are statistically insignificant values at the level of significance 0.05 , meaning that there are no statistically significant differences for the responses of Jordanian university students in the role Universities in the development of middle thought, depending on the college variable for the field of student union, the field of university activities.

This is due to the fact that the Students 'Union and the field of university activities in the role of Jordanian universities in promoting middle thinking according to the previous two fields are not specialized in a specific college or a special section of students but the goal of the Students' Union and activities is directed to all students without exception.

University variable: First: The field of faculty members and the field of students:

Table (10) shows that the value of "F" reached the field of faculty members according to the university variable (0.912) and the field of students (2.552), and they are statistically insignificant values at the level of significance 0.05 , meaning that there are no statistically significant differences for the responses of Jordanian university students in The role of universities in developing intermediate thought, depending on the university variable in the field of faculty members and the field of students.

This is due to the fact that the role of Jordanian universities in developing the middle thought of students and faculty members is one and basic requirement of all faculty members in all universities and that students in any university were in need of this role.

Second: The field of the Student Union and University Activities:

The table shows that the value of "F" in the student union field according to the university variable (8.486) and the field of university activities (4.386) are statistically significant values at the level of significance 0.05 , that is, there are statistically significant differences for the responses of Jordanian university students in the role of universities in developing middle thought Depending on the university variable for the field of student union and the field of university activities, and to find out who the differences are, a comprehensive test was conducted for the dimensional comparisons and the following table shows these results:

Table (11)

Shafi test results for the dimensional comparisons of the responses of the University of Jordan students, according to the university variable, the field of student union and university activities

\begin{tabular}{|l|l|l|l|}
\hline Area & Dimensions & Yarmouk & Mutah \\
\hline \multirow{2}{*}{ Students' Union } & University of Jordan & 0.0686 & $0.6008^{*}$ \\
\cline { 2 - 4 } & Yarmouk & & $0.5322^{*}$ \\
\hline \multirow{2}{*}{ University activities } & University of Jordan & -0.0154 & $0.3857^{*}$ \\
\cline { 2 - 4 } & Yarmouk & & $0.4010^{*}$ \\
\hline
\end{tabular}

* Statistically significant at the significance level 0.05

Table (11) shows that there are statistically significant differences for the responses of Jordanian university students in the role of universities in developing intermediate thought, depending on the university variable for the field of student union and the field of university activities. And there are differences between Yarmouk University and Mu'tah University in favor of Yarmouk University, and the absence of differences between the University of Jordan and Yarmouk University.

The researcher attributes this result, which is the presence of statistically significant differences between the Jordanian universities for the benefit of the University of Jordan, according to the field of the Student Union and University Activities. In the center of the capital and occupies a place in the hearts of Jordanians, it also contains a distinguished educational staff with experience and knowledge and subject to continuous education through research, courses, seminars, etc., in addition to that the students Union at the University of Jordan is ancient and oldest and has a prominent role during the student elections.

The academic year variable: the field of faculty members, the field of students, and the field of student union.

Table (10) shows that the value of "F" amounted to the field of faculty members according to the variable for the academic year (10.444) and the field of students (6.914) and the field of student union $(4,955)$ which are statistically significant values at the level of significance 0.05 , that is, there are statistically significant differences The responses of Jordanian university students to the role of universities in the development of 
intermediate thought, according to the variable of the academic year for the field of faculty members, students and students union. Statistics of Jordanian university students 'responses to the role of universities in developing middle thinking, depending on the variable of the school year in the field of university activities.

To find out who the differences are in the field of faculty members, students, and students' union, according to the variable of the study year, a shafi test was conducted for the dimensional comparisons and the following table shows these results:

Table (12)

Shafi test results for the dimensional comparisons of the responses of the University of Jordan students according to the variable of the academic year for the fields of faculty members, students and students union

\begin{tabular}{|l|l|l|l|l|}
\hline Area & Dimensions & the second & The third & Fourth \\
\hline \multirow{4}{*}{ Faculty members } & The first & 0.2199 & 0.2217 & $0.6461^{*}$ \\
\cline { 2 - 5 } & the second & & 0.0018 & $0.4262^{*}$ \\
\cline { 2 - 5 } & The third & & & $0.4245^{*}$ \\
\hline \multirow{4}{*}{ Students } & The first & 0.0848 & 0.0485 & $0.6009^{*}$ \\
\cline { 2 - 5 } & the second & & -0.0363 & $0.5162^{*}$ \\
\cline { 2 - 5 } & The third & & & $0.5525^{*}$ \\
\hline \multirow{3}{*}{ Students' Union } & The first & 0.1894 & 0.1241 & $0.6981^{*}$ \\
\cline { 2 - 5 } & the second & & -0.0654 & $0.5086^{*}$ \\
\cline { 2 - 5 } & The third & & & $0.5740^{*}$ \\
\hline
\end{tabular}

* Statistically significant at the significance level 0.05

Table (12) shows that there are statistically significant differences for the responses of Jordanian university students in the role of universities in developing intermediate thinking according to the variable of the academic year for the field of faculty members and students and the students Union. The differences came between the first year and the fourth year and in favor of the first year, there are differences between the year. The second and fourth years are in favor of the second year, and there are differences between the third and fourth years and in favor of the third year.

The table shows that there are no differences between the first year and the second year, and between the first and third years, and between the second and third years in the fields of faculty members, students, and the Student Union.

The field of university activities according to the variable of the academic year: The absence of statistically significant differences for the responses of Jordanian university students in the role of universities in developing intermediate thinking according to the variable of the academic year for the field of university activities.

The researcher attributes this result to the fact that the official Jordanian universities pursue the same policy in university activities, as it is a general policy for the university, and students need the same programs in all universities, because the Jordanian society is a similar society in terms of needs and the environment that do not differ greatly between students and that they need programs that circulate and promote dialogue and respect for opinion The other opinion and tolerance.

GPA: Depending on the field of faculty members and university activities:

Table (10) shows that the value of "F" reached the field of faculty members according to the cumulative average variable (1.813) and the field of university activities (2.401) which are statistically insignificant values at the level of significance 0.05 , that is, there are no statistically significant differences for the responses of university students Jordanian in the role of universities in the development of average thought, according to the variable cumulative average for the field of faculty members and university activities.

The researcher attributes this result to the fact that the faculty provides knowledge and knowledge to everyone without exception, as well as university activities are activities for all students without exception and directed to all.

\section{Student field and student union field:}

The value of " $F$ " for the students field according to the cumulative average variable (3.975) and the field of student union (4.018) are statistically significant values at the level of significance 0.05 , that is, there are statistically significant differences for the responses of Jordanian university students in the role of universities in the development of intermediate thinking according to variable The cumulative average for the student field and the student union, and to find out who the differences are, a comprehensive test was conducted for the dimensional comparisons and the following table shows these results: 
Table (13)

Shafi test results for the dimensional comparisons of the responses of students of the University of Jordan, according to the cumulative average variable for the field of students and the student union

\begin{tabular}{|l|l|l|l|l|}
\hline Area & Dimensions & Very good & Good & Acceptable \\
\hline \multirow{4}{*}{ Students } & Excellent & -0.2556 & 0.0285 & -0.0252 \\
\cline { 2 - 5 } & very good & & $0.2481^{*}$ & 0.2304 \\
\cline { 2 - 5 } & good & & & -0.0537 \\
\hline \multirow{3}{*}{ Students' Union } & Excellent & -0.2642 & 0.0202 & -0.3448 \\
\cline { 2 - 5 } & very good & & $0.2844^{*}$ & -0.8006 \\
\cline { 2 - 5 } & good & & & -0.3650 \\
\hline
\end{tabular}

*Statistically significant at the significance level 0.05

Table (13) shows that there are statistically significant differences for the responses of Jordanian university students in the role of universities in the development of intermediate thinking, according to the variable of the cumulative average, the field of students and the student union.

The table shows that there are no statistically significant differences for the responses of Jordanian university students in the role of universities in developing intermediate thinking according to the cumulative average variable for the rest of the levels of the cumulative average variable.

This result is attributed to the fact that students who excel in their field of study and those who have achieved a very good rate are the most students who respond, the most able to analyze and learn, and have sufficient awareness and a sense of the importance of the social issues that we live in and political, and because they have more readings and reading of the scene than those who got a lower rate and they have an opportunity to cooperate with the students 'Union more than others, because it develops their personalities and meets their aspirations, and students who obtain these rates enjoy a balance between studying and learning and student participation.

For the overall score of the scale, arithmetic mean and standard deviations were extracted for the responses of Jordanian university students in the role of universities in developing intermediate thought, depending on gender, college, university, and academic level variables, the cumulative average and the following table shows these averages.

Table (14)

Arithmetic mean and standard deviations for the responses of Jordanian university students in the role of universities in developing intermediate thought, depending on gender, college, university, academic level, and grade point average

\begin{tabular}{|l|l|l|l|l|}
\hline variable & Variable levels & No. & Arithmetic mean & standard deviation \\
\hline College & Scientific & 258 & 3.33 & 0.693 \\
\cline { 2 - 5 } & Humanities colleges & 142 & 3.55 & 0.616 \\
\hline \multirow{4}{*}{ University } & University of Jordan & 196 & 3.53 & 0.617 \\
\cline { 2 - 5 } & Yarmouk & 94 & 3.47 & 0.674 \\
\cline { 2 - 5 } & Mutah & 110 & 3.14 & 0.702 \\
\hline academic year & First year & 98 & 3.61 & 0.604 \\
\cline { 2 - 5 } & Second Year & 129 & 3.47 & 0.664 \\
\cline { 2 - 5 } & Third Year & 88 & 3.48 & 0.596 \\
\cline { 2 - 5 } & fourth year & 85 & 3.02 & 0.698 \\
\hline \multirow{5}{*}{ Cumulative average } & Excellent & 91 & 3.39 & 0.668 \\
\cline { 2 - 5 } & very good & 144 & 3.53 & 0.624 \\
\cline { 2 - 5 } & Good & 123 & 3.28 & 0.605 \\
\cline { 2 - 5 } & Acceptable & 42 & 3.42 & 138 \\
\hline
\end{tabular}

Table (14) shows the existence of apparent differences in arithmetic mean and standard deviations of the responses of Jordanian university students in the role of universities in developing intermediate thought, according to gender, college, university, and academic level variables, and the cumulative average. The hexagon and the following table show these results: 
Table (15)

Analysis of hexagonal variance of responses to the responses of Jordanian university students in the role of universities in the development of intermediate thinking in sub-domains according to study variables

\begin{tabular}{|l|l|l|l|l|l|}
\hline Source & $\begin{array}{l}\text { Sum of } \\
\text { squares }\end{array}$ & $\begin{array}{l}\text { Degrees } \\
\text { freedom }\end{array}$ & $\begin{array}{l}\text { Average } \\
\text { squares }\end{array}$ & $\begin{array}{l}\text { "F" } \\
\text { value }\end{array}$ & $\begin{array}{l}\text { Statistical } \\
\text { significance }\end{array}$ \\
\hline College & 1.724 & 1 & 1.724 & 4.342 & $.038^{*}$ \\
\hline University & 3.380 & 2 & 1.690 & 4.257 & $.015^{*}$ \\
\hline academic year & 9.021 & 3 & 3.007 & 7.574 & $.000^{*}$ \\
\hline $\begin{array}{l}\text { Cumulative } \\
\text { average }\end{array}$ & 3.432 & 3 & 1.144 & 2.881 & $.036^{*}$ \\
\hline The error & 154.835 & 390 & .397 & & \\
\hline Overall & 181.827 & 399 & & & \\
\hline
\end{tabular}

* Statistically significant at the level of 0.05

Table (15) shows that the value of " $F$ " for the responses of Jordanian university students in the role of universities in developing middle thought according to the university variable amounted to (4.342), which is a statistically significant value at the level of significance 0.05 , meaning that there are differences in the responses of Jordanian university students in the role of universities In developing intermediate thought according to the variable of the college, the differences came in favor of human colleges.

Table (15) shows that the value of "F" for the responses of Jordanian university students in the role of universities in developing middle thought according to the university variable was (4.257), which is a statistically significant value at the level of significance 0.05 , meaning that there are differences in the responses of Jordanian university students in the role of universities In developing intermediate thought according to the university variable, and to find out who the differences are, a comprehensive test was conducted for the dimensional comparisons and the following table shows these results:

Table (16)

Shafi test results for the dimensional comparisons of the responses of the University of Jordan students according to the university variable for the overall scale of the scale

\begin{tabular}{|l|l|l|}
\hline Dimensions & Yarmouk & Mutah \\
\hline University of Jordan & 0.0631 & $0.3910^{*}$ \\
\hline Yarmouk & & $0.3279^{*}$ \\
\hline
\end{tabular}

* Statistically significant at the significance level 0.05

Table (16) shows that there are statistically significant differences for the responses of Jordanian university students in the role of universities in developing intermediate thinking according to the university variable for the overall degree of the scale and the differences came between the University of Jordan and Mu'tah University in favor of the University of Jordan. And there are differences between Yarmouk University and Mu'tah University in favor of Yarmouk University, and the absence of differences between the University of Jordan and Yarmouk University.

Table (15) shows that the value of "F" for the responses of Jordanian university students in the role of universities in developing middle thought according to the variable for the academic year amounted to (7.574), which is a statistically significant value at the level of significance 0.05 , meaning that there are differences in the responses of Jordanian university students in the role Universities in developing intermediate thought according to the variable of the school year, and to find out who the differences are, a comprehensive test was conducted for the dimensional comparisons and the following table shows these results:

Table (17)

Shafi test results for the dimensional comparisons of the responses of the University of Jordan students according to the variable of the academic year for the overall degree of scale

\begin{tabular}{|l|l|l|l|}
\hline Dimensions & The second & The third & The fourth \\
\hline The first & 0.1433 & 0.1280 & $0.5912^{*}$ \\
\hline the second & & $0.0153-$ & $0.4479^{*}$ \\
\hline The third & & & $0.4632^{*}$ \\
\hline
\end{tabular}

* Statistically significant at the significance level 0.05

Table (17) shows that there are statistically significant differences for the responses of Jordanian university students in the role of universities in developing intermediate thought according to the variable of the school year for the total degree of the scale and the differences came between the first year and the fourth year in favor of the first year, and the existence of differences between the second and fourth years in favor of the year The second, and the existence of differences between the third and fourth years and in favor of the third year. And there are no differences between the rest of the academic year levels.

The researcher attributes this result to several reasons, including that the educational system in Jordan is in 
continuous development and improvement, and this in turn is reflected on students, their ideas and their way of thinking, and that the curricula contain a scientific material that nurtures intermediate thought and invites him and his examples are the Amman message, where it was introduced to Jordanian curricula, and the impact of programs Religious and media that publish the values of tolerance and respect for the other and show the dangers that accrue to society and the individual as a result of being away from the right and sound thought, just as the media has a role as well. , Have become beneficial and bear fruit, which drives more of these activities.

The researcher also attributes this result to the fact that students in the first and second academic years are far from these academic stages away from intellectual and political trends that may take them to different directions, and that students in these stages need to support and promote moderate thought and promote the values of tolerance, moderation, and moderation, so that they become entrenched and not influenced by ideas Subversion.

Table (15) shows that the value of "F" for the responses of Jordanian university students in the role of universities in developing the average thought according to the cumulative average variable was $(2.881)$, which is a statistically significant value at the level of significance 0.05 , meaning that there are differences in the responses of Jordanian university students in the role Universities in the development of intermediate thought, depending on the variable GPA. To find out who the differences are, a comprehensive test of dimensional comparisons was performed and the following table shows these results:

Table (18)

Shafi test results for the dimensional comparisons of the responses of the University of Jordan students according to the cumulative average variable for the overall degree of scale

\begin{tabular}{|l|l|l|l|}
\hline Dimensions & v.good & good & Acceptable \\
\hline Excellent & -0.1485 & 0.1109 & -0.0098 \\
\hline v.good & & $0.2594^{*}$ & 0.1584 \\
\hline good & & & -0.1011 \\
\hline
\end{tabular}

* Statistically significant at the significance level 0.05

Table (18) shows that there are statistically significant differences for the responses of Jordanian university students in the role of universities in developing intermediate thought according to the variable of the cumulative average and the differences came between the very good and the good rate and in favor of the very good rate.

The researcher attributes this result to the fact that the students who obtain this average are sufficient to obtain scientific and cultural knowledge and the scientific repository as a result of interest and learning, and thus they obtain a degree of awareness of the middle thought enabling them to think correctly and correctly.

\section{Recommendations:}

Based on the results of the study, the researcher recommends the following:

-1-The need for universities to pay attention, through its various scientific, research and service channels, to spreading a culture of moderation among its professors and students.

-2-The need to work on employing the various means of culture, media, communication and learning in all its stages to highlight the values of moderation and moderation.

-3-The importance of spreading awareness of moderation among college students, so that they are aware of the risks and drawbacks of militancy and hyperbole.

-4- Holding conferences and seminars to discuss mediation issues in the university community.

-5- The contribution of the various educational institutions to highlight the milestones of moderation through the diversity of programs that they offer to educate the student in an integrated education.

-6- Working to clarify the true meaning of Islamic moderation.

-7- Providing students and faculty with a curriculum on the Amman dissertation.

-8- Establishing educational policies that include all kinds of thinking and citizenship, adopting a policy of dialogue and respecting the opinions of others.

-9- Intensifying religious and social programs that call for tolerance and respect for others.

-10- Focusing on purposeful critical thinking and adopting scientific methods to reach the truth.

-11- Focusing on university activities and activating the role of students through the Students' Union.

\section{Sources and references}

The Holy Quran.

Abu Jabr, Adnan Hamdan 2014)), the role of faculty members in the Islamic University in promoting the principle of moderation in their students and ways to activate it, unpublished Master Thesis, Islamic University of Gaza / Palestine.

Anis, Ibrahim and others, Lexicon of the mediator, Islamic Library Istanbul, Turkey, 'i 2, part two, p. 698.

Baabad, Ali Hood 2011)), the role of universities and educational and cultural institutions in promoting moderation among Arab youth, conference: the role of Arab universities in promoting the principle of 
moderation among Arab youth, publisher: Taibah University.

Al-Bishri, Ayesh bin Attia (2011), the role of the university in promoting the principle of moderation among its students through Islamic education activities Conference: the role of Arab universities in promoting the principle of moderation among young people, publisher: Taibah University, Medina.

Al-Bakkar, Abdul Karim 2017)), thought is its nature and importance, www. said.net

Bani Saleh, Hussein (2005), Reading in the Oman Message, Risalat Al-Muallem Magazine, 44 (1), pp. 34-44.

Al-Harahsheh, Mahmoud Ali 2018)), King Abdullah II's Views in Promoting Moderation and Moderation Values Amman Message and Discussion Papers: Case Study, Unpublished Master Thesis, Al-Bayt University, Jordan.

Al-Hasnawi, Mwafaq 2010)), the university's role in building the student's personality, "http://www.al noor.se/article.asp, retrieved on: 10/28/2019 at: $11 \mathrm{am}$.

Al Hassoun, Alaa 2003), Awareness Development, 1st Edition, Iran Dar Al-Ghadeer.

Khasawneh, Anwar (2005), The Message of Oman: Lessons and Through the Journal of the Message of the Teacher, 44 (1): 54-60.

Al-Khatib, Muhammad 2009)), Mechanisms for Propagating Moderate Thought, The First International Symposium The World Forum on Moderation, Consolidating Moderate Thought in the Islamic World Series of Moderation Thought (28): Amman-Jordan, (pp. 50) 15-12 / 2009-

Al-Khawaja, Majed 2005) Amman Al-Madinah, a vivid example of the Amman Message, Risalat Al-Muallem Magazine, 44 (1) Amman, 3.

Rababaa, Muhammad Ahmad (2007) Building intermediate thinking among students, Risalat al-Muallem, vol. 45 p, 2, pp. 19-97.

Zakzouk, Mahmoud Hamdi (2012), Religious Thought and Contemporary Issues, Cairo: The General Book Authority.

Al-Zayat, Montaser (2009), the role of moderation in the renaissance of Yemen, the first international symposium, the World Forum on Moderation, the consolidation of moderate thought in the Islamic world, Amman, Jordan, Series of Moderation Thought (28), p. 18.

Al-Saeedat, Ismail Muhammad (2015), a study of moderate Islamic educational discourse: the Amman Message as an example, Zarqa University: Amman - Jordan.

Shdifat, Ya`qub (2005), Amman Message: Educational Illuminations, Resala’s Teacher Magazine. (44) (1): 6163.

Al-Sharia, Nasser and Al-Balasi, Saud (2011), features of moderation in the personality of the university professor, a field study, a research paper presented to the conference of the role of Arab universities in promoting the principle of moderation among Arab youth held at Taibah University, Medina, Saudi Arabia, on: 1-4 Rabi ' Al-Akher 1432 AH / 6-9 March 2011.

Al-Saghir, Ahmed (2005), University Education in the Arab World (Challenges of Reality and Visions of the Future) Books World, 1st edition, Cairo.

Al-Furayat, Ghaleb (2009), Higher Education: Reality and Ambition, Azmina Printing and Publishing House, 1st edition, Amman.

Arad, Saleh (2011), The Educational Contents of Moderation and the Role of the University in its Application, Journal of the Federation of Arab Universities, Publisher: Union of Arab Universities - General Secretariat, pp. $260-231$, p. 61

Al-Ghoul, Muhammad and Judges, Alaa (2019), Islam and Life, Jordan: Dar Al-Hamid for Publishing and Distribution.

Al-Faouri, Marwan (2009), World Forum on Moderation, Idea and Content, First International Symposium, World Forum on Moderation, Consolidation of Moderate Thought in the Islamic World, Series of Moderate Thought (28) Amman: Jordan, (11, 108).

Al-Fayez, Hamza Nawwaf (2017), The Role of Jordanian Political Discourse in Defending the Moderation of Islam: The Amman Messageas a Model, Unpublished Master Thesis, Middle East University: Amman Jordan.

Al-Furfour, Muhammad, Abdul Latif Saleh (2002) Characteristics of Islamic Thought, Dar Al-Maktabi - p. 28.

Al-Furayat, Ghaleb (2009) Higher Education: Reality and Ambition, Azmina Printing and Publishing House, 1st edition, Amman.

Al-Fandi, Abdel-Salam Atwa (2013) Raising a child in Islam, Amman, Dar Al-Masirah, 1st floor.

Al-Qaradawi, Youssef (2011), words in Al-Wasatiya and its landmarks, Dar Al-Shorouk: Cairo.

Judges, Muhammad Ahmad (2008), University Youth, Challenges of Modernity and Tradition, Second Cultural Conference, Princess Sumaya University, p. 213.

Judges, Muhammad Amin (2014), the degree of the prevalence of irrational ideas among students of the universities of Mutah and Hashemite in the Hashemite Kingdom of Jordan and their relationship to some variables, Damascus University Journal for Educational and Psychological Sciences, vol. 30, p. 1 
Mohamed, Metwally (2003), Tomorrow Without Terrorism, The Egyptian Center for Research and Studies, Amman: 1 p. 173.

Al-Nasser, Ibrahim Abdullah (2003), Educational Sociology, Amman: Wael Printing and Publishing House.

Grace, Ibrahim (2012), Moderation in Islamic Perception, Amman: Dar Al-Mamoun, 3rd floor.

Hawari, Maraj Abd al-Qadir (2011), the role of universities in promoting the principle of moderation and intellectual security for students, a field study on the University of Laghouat in Algeria, publisher: Taibah University, the Conference of Arab Universities in promoting the principle of moderation.

Abdullah, A.and Saeed, M. (2016), Extremism in Education in Pakistan: University Teachers' Thoughts, Ankara University, Journal of Faculty of Educational Sciences, 49(2): 55-69.

Abu Amshah\& Al-Qudah (2020), The Challenges Hindering the Promotion of a Culture of Integrity at Jordanian Universities, Journal of Education and Practice, 11(16): 134147>

Ben Tarif, E \& Al-Qudah, M. (2019). International Journal of Advanced Science and Technology The Reality about the Educational Capabilities of the Jordanian Women in preventing their Sons / Daughters from Adopting Fanatical Ideologies, Journal of Advanced Science 13(4):214-227

Davydov,D.(2015), The Causes of Youth Extremism and Ways to brevent It inthe Educational Environment,Russian Social Science Review,56(5),pp.51-6

Fallouh, R \& Al-Qudah, M (2020) The Capability to Predict the Behaviors of the Students Enrolled in Jordanian Universities Through Their Aesthetic Values, Journal of Education and Practice, 11(4): 104-114.

Fatkhova, R; Mingazova, D. (2016). Diagnostics of Teenagers Disposition to Destructive Communication as Way of Youth Extremism Prevention. Global Media Journal, American Edition, 1(1):5-45.

Al-Hammad, A \& Al-Qudah, M. (2019,1). Role of Jordanian Universities in Educating Students on Entrepreneurship from the Point of View of Juggling Students, An Interdisciplinary Journal for Science and Technology Studies, 13(1): 167-180

Al-Hammad, A \& Al-Qudah, M. (2019,2). Role of the Jordan educational system in guiding students to vocational education from their teachers point of view, An Interdisciplinary Journal for Science and Technology Studies, 13(1): 153-166.

Hatahet. F \&Alquda, M. (2016). Family Problems Experienced by Students of the University of Jordan, European Scientific Journal (12)13: 145-156

Heilat, M \& Al-Qudah, M\&\& AL-Rbabaah, J. (2008) The relationship between family socialization patterns and emotional disturbance among 6th grade male students ,Association of Arab Universities Journal for Education and Psychology, 1(6): 1-34.

Jose,m(2008) GLObliziation,education,and cultural diversity, In educational therories.

Malkawi, S \&Al-Qudah, M. (2018, 1). Reality and Obstacles of the Partnership between Family and School in Jordan, Modern Applied Science, 2(12), 81-92.

Malkawi, S \&Al-Qudah, M. (2018, 2). The Reality of Partnership Between The Family and The School from The Perspective of Teachers' Working in Irbid First Education Directorate, Dirasat: Educational Sciences, 45(3): 209-225

Al-Muhammady, (2018), The Role of Universities and Schools in Countering and Preventing Violent Extremism: Malaysian Experience, Centre for Islamization (CENTRIS), International Islamic University Malaysia.

Al-Qudah, M (2006). The Relationship between Family Socialization Patterns and Some Personality Attributes Female Undergraduates at Mu'tah University, Jordan Journal of Educational Sciences,2(3):155-168.

Al-Qudah, M (2017). The Extent University of Jordan Students Represent Islamic Values from Their Perspective, Dirasat: Educational Sciences,44(4), 9: 257-275.

Al-Qudah, M \& Hathal, S (2019). The Participation of Female Students at the University of Jordan in Political Life and the Obstacles Encountered from Their Viewpoints, International Journal of Advanced Science and Technology, 13(3): 1-9.

Al-Qudah, M \& Al-Zboon, M. S. \& Al-Ashqar, A. A(2016).The Degree of Resistance to Temptation among the Students of the University of Jordan and its Relationship to the Pattern of Family Upbringing, European Journal of Social Sciences 52(3): 280-29.

Al-Qudah, M \& Hindi, M (2019). Environmental values included in Science Books for the 10th Grade in Jordan "An Analytical Study”, An Interdisciplinary Journal for Science and Technology Studies, 13(1): 135144.

Qamweh, M \& Al-Qudah, M (2017) A Proposed Educational Guide to Help Working Woman to Match between Works and Raising Children, Dirasat: Educational Sciences, (44)4, 6: 109-139.

Al-Shami, S \& Prof. Al-Qudah, M. (2020). Teaching Against Extremist Ideologies Through Evidence Obtained from the Holy Quran, Journal of Education and Practice, 11(13): 122-128.

Al-Tamimi, A \& Al-Qudah, M.A (2019) The Relationship between the parenting Styles of the Students of the First Three Grades with their Level of Creativity, An Interdisciplinary Journal for Science and 
technology Studies, (13)01: 123-134

Al-Turk. R \& Al-Qudah, M. (2017). The Jordanian Universities Students Practicing Degree of Thinking Skills, Dirasat: Educational Sciences, 44(4),6: 73-91.

Al-Zoby, K \&Al-Qudah, M, (2020) Promoting Positive Behaviors among the Lower Primary School Students, Journal of Education and Practice, 11(8): 89-102.

Zaza, H \&Heilat, M \& Al-Qudah, M. (2012). The acquisition and practicing degree of ministry of education teachers in Jordan for instruction strategies and evaluation based knowledge economy, Journal of King Saud university: Education science \& Islamic studies, (24)3: 619-652.

المواقع الإكترونية:

: https://www.alukah.net/culture/0/108911/\#ixzz6CV6Bd0yz

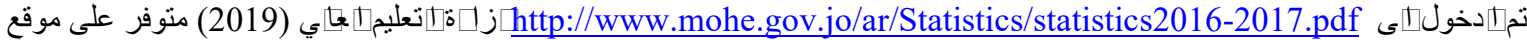

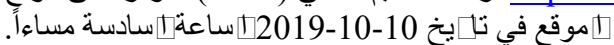

hأسترجع بتاليخ 10/24ttps://faculty.psau.edu.sa

. فttps://www.ammonnews.net/index.php.

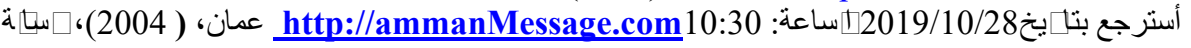

